\title{
EFFECT OF HEALTH EDUCATION ON KNOWLEDGE AND ATTITUDES OF PREGNANT WOMEN AT KALIJAGA COMMUNITY HEALTH CENTER, CIREBON, WEST JAVA
}

\author{
Yeni Fitrianingsih, Pepi Hapitria \\ Study Program of Midwifery, School of Health Polytechnics, \\ Ministry of Health Tasikmalaya, Cirebon, West Java
}

\begin{abstract}
Background: Health education is all activities that enhance knowledge, attitude, good practice of individuals, groups or communities, in maintaining and improving their own health. Health education may be more effective in improving knowledge and attitude of pregnant women if delivered with suitable media. This study aimed to analyze the effects of health education with media assistance to knowledge and attitudes about health in pregnant women.

Subjects and Method: This study was a randomized controlled trial carried out at Kalijaga community health center, Cirebon City, West Java. A sample of 30 pregnant women was divided into 3 groups by randomization: (1) 10 pregnant women who received health education about pregnancy using flipchart, (2) 10 pregnant women who received health education about pregnancy using multimedia, and (3) 10 pregnant women who received health education about pregnancy using music box. Data were collected by questionnaire and analyzed by Kruskal-Wallis to test the differences between the three groups, followed by the Mann Whitney to test group pairs.

Results: The knowledge scores in the multimedia group and the music box group were higher than the flipchart group, with $\mathrm{p}=0.001$. Attitude score on the multimedia group and music box group was higher than flipchart group, with $p=$ 0.023. The score of knowledge in the multimedia group was about equal to the music box group, with $\mathrm{p}=0.342$. Attitude score on the multimedia group was about equal to the music box group, with $\mathrm{p}=0.517$.

Conclusion: Health education using multimedia or music box is more effective than a flipchart to improve knowledge and attitudes about the health of pregnant women. Health education using multimedia or music box shows comparable effectiveness.
\end{abstract}

Keywords: health education, knowledge, attitude, multimedia, music box, flipchart, pregnant women

\section{Correspondence:}

Yeni Fitrianingsih. Study Program of Midwifery, School of Health Polytechnics, Ministry of Health Tasikmalaya, Jl. Cilolohan No.35, Kahuripan, Tawang, Tasikmalaya 46115, West Java. Email: yfitiraningsih44@gmail.com.

Mobile: 082116122264 